\title{
水稲出穗期における潮風の影響 $(2)^{*}$
}

坪井八十二・中川行夫

(農業技術研究所気象科)

Effects of Briny Wind on the Rice Plant in the Heading Stage (2)

Y. TSUBOI and Y. NAKAGAWA

(Division of Meteorology, National Institute of Agricultural Sciences)

\section{緒言}

台風の際しばしば見られるように，水稲の出穗開花期 飞潮風が吹いた場合には激甚な被害となる。この原因は 風によつて，傷付いた作物体に塩分が付着することによ り $\mathrm{Cl}$ の直接的害作用の他飞, 激しい脱水作用が起る ことによるものと考兄れる。

前報)に执いて 1 穂当り $\mathrm{NaCl}$ で 4〜 $6 \mathrm{mg}(\mathrm{Cl}$ で 2.5 $\sim 4 \mathrm{mg}$ ）以上塩分が付着した場合には被害が認められ，

また穗の水洗は処理後速かに行 5程，回復が大であるこ とが示された。しかし潮風処理としては予め塩水に穂を 瞬間浸したものを風に当てるといら方法をとつた。この 方法では穂の久塩分が付着することになる。実際の潮風 の場合は監分を含んだ風が作物体に当るので，この方法 とはかなり相違することが考兄られる。そこで処理方法 を改めて昭和 31 年， 32 年に実験を行つたので，その結 果を報告する。

\section{実 験 方 法}

潮風処理の方法としては, 風洞で毎秒約 $12 \mathrm{~m}$ の強風 を発生させ，之の強風中で動力噴霧機により種々の濃度 の塩水をノズルから噴出させた。噴霧機の圧力は 100 $\mathrm{lb} / \mathrm{in}^{2}$ であり，またノズルとポットの間隔は約 $2 \mathrm{~m}$ で あつた。実験に使用した水稲は両年とも農林 37 号で, 予めポツト栽培をした稲を出穂後 7 日乃至 10 日の時期 に風洞に搬入して, 上記の潮風処理を 3 時間行つた。比 較のために無処理区と風単独処理区を設けた。さらに潮 風処理の 1 部を昭和 31 年度は処理後 24 時間, 昭和 32 年度は 6 時間, 12 時間に水洗し, 水洗効果を調査し た。潮風処理直後, 処理した稲の穗及び止葉を一部切り 取り，それらに付着した塩分量 $(\mathrm{Cl})$ を MOHR 氏法に よつて分析した。また処理後に外観的被害調査及び収穫 物調査を行つた。

\section{実 験 結 果}

昭和 31 年の実験では塩水濃度 $5.56 \%, 2.78 \%$ 及び $1.39 \%$ の 3 種類の塩水を噴霧したが，最高濃度の処理 区は上玄米が皆無となり，被害の限界濃度を求めること

\footnotetext{
* 1958 年 2 月 14 日 関東支部総会に打いて発表
}

ができなかつたので, 昭和 32 年度には最高濃度を 2.78 \%とし, 低濃度の処理区を増加した。従つて実駼結果は 昭和 32 年のものを中心に述べることとする。

a) 付着塩分量

処理後穂及び葉に付着した塩分量を分析した所，第 1 表の如き結果がえられた。

第 1 表 処理区及び塩分付着量

\begin{tabular}{|c|c|c|c|c|c|c|c|}
\hline \multirow{3}{*}{\multicolumn{2}{|c|}{ 処理区 }} & \multicolumn{2}{|l|}{ 略 } & 号 & \multirow{3}{*}{$\begin{array}{l}\text { 塩水 } \\
\text { 濃度 }\end{array}$} & \multirow{3}{*}{$\begin{array}{l}1 \text { 穂に } \\
\text { 付着し } \\
\text { た } \mathrm{Cl} \\
\text { 量 }\end{array}$} & \multirow{3}{*}{$\begin{array}{l}\text { 止葉の10 } \\
\mathrm{cm}^{2} \text { と付 } \\
\text { 着した } \\
\mathrm{Cl} \text { 量 }\end{array}$} \\
\hline & & \multirow{2}{*}{ 非水洗 } & \multirow{2}{*}{$\begin{array}{c}\text { 水 } \\
6 \text { 時 } \\
\text { 間後 }\end{array}$} & \multirow{2}{*}{$\begin{array}{l}\text { 洗 } \\
\text { 12時 } \\
\text { 間後 }\end{array}$} & & & \\
\hline & & & & & & & \\
\hline \multirow[b]{2}{*}{ 潮 } & A & $A_{1}$ & $\mathrm{~A}_{2}$ & $A_{3}$ & $2.78^{\%}$ & 6. 36 & 1. ${ }^{\mathrm{mg}}$ \\
\hline & B & $\mathrm{B}_{1}$ & $\mathrm{~B}_{2}$ & $\mathrm{~B}_{3}$ & 1. 39 & 2.69 & 1.10 \\
\hline \multirow{3}{*}{$\begin{array}{l}\text { 風 } \\
\text { 区 }\end{array}$} & $\mathrm{C}$ & $\mathrm{C}_{1}$ & $\mathrm{C}_{2}$ & $\mathrm{C}_{3}$ & 0.70 & 1.67 & 0.63 \\
\hline & D & $D_{1}$ & $\mathrm{D}_{2}$ & $\mathrm{D}_{3}$ & 0.35 & 0.68 & 0.35 \\
\hline & $\mathrm{E}$ & $E_{1}$ & $\mathrm{E}_{2}$ & $\mathrm{E}_{3}$ & 0.17 & 0.32 & 0.35 \\
\hline \multicolumn{2}{|c|}{ 風 区 } & \multicolumn{3}{|c|}{$\mathrm{W}$} & & & \\
\hline \multicolumn{2}{|c|}{ 対照区 } & \multicolumn{3}{|c|}{$\mathrm{K}$} & & & \\
\hline
\end{tabular}

b) 処理時の気象条件

処理は 3 日間にわたり 6 回行つたので，処理時の気象 条件は第 2 表に示す如く，同一ではないが，極端な違い はなかつた。ただし 9 月 12 日の処理 (E及びW区) は 他に比べてやや高温低湿であつた。

第 2 表 気 象 条 件

\begin{tabular}{|c|c|c|c|c|}
\hline 処理| & 処 理 日 及 び 時 刻 & $\begin{array}{l}\text { 平均 } \\
\text { 気温 }\end{array}$ & 平均 & 風速 \\
\hline $\begin{array}{l}\text { A } \\
\text { B }\end{array}$ & $\begin{array}{r}9 \text { 月 } 10 \text { 日 }(9.30 \sim 12.30) \\
(13.10 \sim 16.10)\end{array}$ & $\begin{array}{l}{ }^{\circ} \mathrm{C} \\
20.5 \\
20.6\end{array}$ & $\begin{array}{r}\% \% \\
95.6 \\
96.4\end{array}$ & \begin{tabular}{|c|}
$\mathrm{m} / \mathrm{s}$ \\
11.9 \\
11.9
\end{tabular} \\
\hline $\begin{array}{l}\mathrm{C} \\
\mathrm{D}\end{array}$ & 9 月 11 . 早 $(4.00 \sim 7.00)$ & $\begin{array}{l}17.8 \\
17.6\end{array}$ & $\begin{array}{l}94.7 \\
95.7\end{array}$ & $\begin{array}{l}11.9 \\
11.9\end{array}$ \\
\hline $\begin{array}{l}\mathrm{E} \\
\mathrm{W}\end{array}$ & $\begin{array}{r}9 \text { 月 } 12 \text { 日 }(9.20 \sim 12.20) \\
(12.25 \sim 15.25)\end{array}$ & $\begin{array}{l}23.6 \\
24.3\end{array}$ & $\begin{array}{l}85.6 \\
89.1\end{array}$ & $\begin{array}{l}11.8 \\
11.8\end{array}$ \\
\hline
\end{tabular}

c) 外観的被害の状 況

処理直後ではいずれの区も穂の異常は認められない が 止葉は $\mathrm{A}$ 区は $1 / 2 \sim 2 / 3$ 巻き，全部巻いたものもあ る。B区は 1/2〜1/3 巻き，C区以下は巻いていない。 
5〜7 日後には外観的被害が明瞭になり，A区では止葉 は大半巻いて全部枯れている。穂は灰白色となり枝梗が 全部枯れたものもある。B区では止葉は $1 / 2$ が巻いて 枯れ穗は枝梗 1/2〜1/3 枯れている。C区は止葉の先が わずかに枯れ，穗は枝梗の先がわずかに枯れているが， よく稔つている。 D・E区は 5〜7 日後も葉先の裂傷の 他は殆んど異常を認めなかつた。

\section{a) 収穫物調查結果}

収穫物について収量構成要素について調査した所, 次 の如き結果を得た。

第 3 表 収 量 調 查 結 果

\begin{tabular}{|c|c|c|c|c|c|c|c|}
\hline 処 & 理 & 区 & $\begin{array}{l}\text { 稔実 } \\
\text { 步合 }\end{array}$ & $\begin{array}{l}\text { 上玄米 } \\
\text { 歩合 }\end{array}$ & $\begin{array}{l}\text { 千粒 } \\
\text { 重 }\end{array}$ & $\begin{array}{l}\text { 収量 } \\
\text { 比 }\end{array}$ & $\begin{array}{l}\text { 減收 } \\
\text { 率 }\end{array}$ \\
\hline \multirow[b]{2}{*}{ 潮 } & & & $\begin{array}{r}\% \\
8.7 \\
24.1 \\
25.0\end{array}$ & $\begin{array}{r}\% \\
12.3 \\
42.5 \\
38.5\end{array}$ & $\begin{array}{r}\mathrm{g} \\
18.2 \\
18.2 \\
18.5\end{array}$ & $\begin{array}{r}1.4 \\
13.7 \\
13.2\end{array}$ & $\begin{array}{l}98.6 \\
86.3 \\
86.8\end{array}$ \\
\hline & & & $\begin{array}{l}61.4 \\
63.1 \\
63.0\end{array}$ & $\begin{array}{l}50.7 \\
42.7 \\
50.0\end{array}$ & $\begin{array}{l}17.6 \\
17.3 \\
17.8\end{array}$ & $\begin{array}{l}41.6 \\
34.5 \\
41.5\end{array}$ & $\begin{array}{l}58.4 \\
65.5 \\
58.5\end{array}$ \\
\hline 風 & & & $\begin{array}{l}74.0 \\
75.5 \\
75.6\end{array}$ & $\begin{array}{l}56.3 \\
48.5 \\
48.5\end{array}$ & $\begin{array}{l}18.7 \\
17.7 \\
18.4\end{array}$ & $\begin{array}{l}57.4 \\
48.0 \\
49.8\end{array}$ & $\begin{array}{l}42.6 \\
52.0 \\
50.2\end{array}$ \\
\hline \multirow[t]{2}{*}{ 区 } & & & $\begin{array}{l}73.9 \\
70.8 \\
73.2\end{array}$ & $\begin{array}{l}67.5 \\
54.5 \\
48.6\end{array}$ & $\begin{array}{l}18.2 \\
16.7 \\
17.4\end{array}$ & $\begin{array}{l}66.9 \\
47.6 \\
45.8\end{array}$ & $\begin{array}{l}33.1 \\
52.4 \\
54.2\end{array}$ \\
\hline & & & $\begin{array}{l}75.9 \\
72.8 \\
71.5\end{array}$ & $\begin{array}{l}65.2 \\
63.9 \\
64.9\end{array}$ & $\begin{array}{l}17.5 \\
18.1 \\
18.1\end{array}$ & $\begin{array}{l}63.9 \\
62.2 \\
62.2\end{array}$ & $\begin{array}{l}36.2 \\
37.8 \\
37.8\end{array}$ \\
\hline 風 & & 区 & 71.4 & 62.6 & 18.7 & 61.9 & 38.1 \\
\hline 対 & 照 & 区 & 79.2 & 87.9 & 19.4 & 100 & 0 \\
\hline
\end{tabular}

a）塩分の被害限界濃度

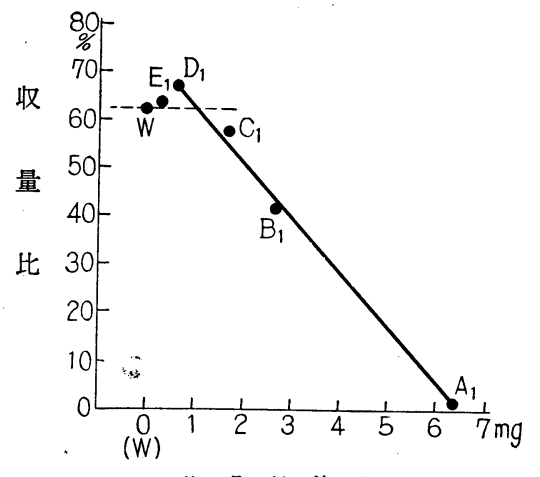

塩 分 付着 量

第 1 図付着塩分量と収量 (32 年)

付着量の関係を示したのが第 1 図である。

この図によると処理区 $\mathrm{D}_{1}, \mathrm{E}_{1}$ の収量は風単独区 $(\mathrm{W})$ の収量を上廻つている。この原因としては塩分濃度の低
い場合は風と同時に霧滴が吹き付けられることとなり， 風による被害が軽減されることが考えられる。また第 2 表に示されているように, $E_{1}, W$ の両区が他の区に比べ て処理時の風の湿度が低かつたために被害が大きくなつ たことも考えられる。詳細は不明であるが，この場合， 風単独区 (W) 以下の収量を示寸場合を潮風被害とすれ ば，被害の限界濃度はC区（1 穂の付着塩分量で 1.67 $\mathrm{mg})$ と区 $(0.68 \mathrm{mg})$ の間にあることがわかる。

実際の潮風害の場合は, 稲の生育時期と生育状態, 風 の強さとその継続時間, その後の天候などによつて異る ことが考えられるが，この実験からは 1 穂の付着塩分量 がほぼ $1.0 \mathrm{mg}$ 前後を被害限界濃度とみなしてよく，塩 水の濃度でいえば $0.6 \%$ 程度となる。（塩水濃度と穂の 付着塩分量の関係は後述)

b) 水洗効果

従来，潮風を受けた稲を水洗することによつて，ある 程度被害の軽減が出来ると言われている。しかしながら 稲の穂や葉に付着した塩分は速かに被害を与えることが 考えられるので，潮風後出来るだけ速やがに水洗した方 が望ましいわけである。

昭和 32 年には，処理後 6 時間及び 12 時間に水洗を してその効果を調べたが，第 2 表を見ると A区（1穂の 付着塩分量が最も多い) では明らかに水洗効果が見られ しかも 6 時間後水洗の方が 12 時間後水洗よりも被害が 軽い。B区以下では水洗区と非水洗区の差異がはつきり しないが，稔実歩合は明らかにB区，C区とも非水洗よ りも良好になつている。

昭和 31 年度の成績では $1.39 \%$ の塩水で処理した区 (昭和 32 年度の B区に該当する) は 24 時間後の水洗 効果が認められている。

これらより，水洗効果は付着塩分量の多い稲ほど効果 が認められるようであり，水洗時期は早いほどよいこと がわかつた。

\section{c）塩水濃度と穂，葉の付着塩分量}

処理に使用した塩水濃度と穂及び葉の付着塩分量の間 には下のような関係が認められた。

1 穂の付着塩分量を $\mathrm{E}$ ，葉 $1 \mathrm{~cm}^{2}$ 当りの付着塩分量を $\mathrm{L}$ ，塩水濃度を $\mathrm{C}$ とすると，

塩水濃度と葉の付着塩分量では

$$
\mathrm{L}=0.78 \mathrm{C} 0.71
$$

穂の付着塩分量と葉の付着塩分量では

$$
\mathrm{E}=3.00 \mathrm{~L} 1.38
$$

といら関係がある。これより塩水濃度の増加に伴う付着 塩分量の増加は，葉よりも穂の方が大きいと言うことが できる。ただしこの実験式は風洞実験のものであるから 
実際の水田に打ける值と比較してみたい。

\section{d) 外観的被害と減収量}

潮風害をうけた後できるだけ早い時期に，外観的変北 から減収量の推定のできることが望ましい。本実験より 処理後に拈ける止葉の巻き方，粐の色などを観察するこ とによつて, 減収の程度が推定できそうであることが認 められた。しかし本年の結果からだけでは未だ十分な資 料が得られなかつたので，今後さらにこのような追究が 必要であろう。第 4 表にその一端を示した。

現地に拉いて, 潮風直後（あるいは 5〜7 日後）の止 葉, 第 2 葉の巻き方 (枯れ方), 粐の色の変色程度等と 減収率との関係を更に調査検討することにより，ょり正 確な減収確定尺度が作成しうるであろう。
第 4 表. 外観的变化と減収量

\begin{tabular}{|c|c|c|c|c|}
\hline \multirow{2}{*}{$\begin{array}{l}\text { 処理 } \\
\text { 区 }\end{array}$} & \multirow{2}{*}{$\begin{array}{l}1 \text { 穂の } \\
\text { 付着塩 } \\
\text { 分量 }\end{array}$} & \multicolumn{2}{|c|}{ 外観 的 被 害 } & \multirow{2}{*}{ 減収率 } \\
\hline & & 処理直後 & $5 \sim 7$ 日 後 & \\
\hline $\mathrm{A}$ & $\begin{array}{l}\mathrm{mg} \\
6.36\end{array}$ & $\begin{array}{l}\text { 止葉 } 1 / 2 \sim \\
2 / 3 \text { 巻 }<\end{array}$ & $\begin{array}{l}\text { 籾の大半灰白色 } \\
\text { 葉全部巻いて枯 } \\
\text { れる }\end{array}$ & 98.6 \\
\hline B & 2. 69 & $\begin{array}{l}\text { 止葉 } 1 / 3 \sim \\
1 / 2 \text { 巻く }\end{array}$ & $\begin{array}{l}\text { 止葉 } 1 / 2 \text { 枯れる } \\
\text { 䊏は可成り稔つ } \\
\text { ている }\end{array}$ & 58.4 \\
\hline $\mathrm{C}$ & 1.67 & 止葉巻かな & 殆んど異常なし & 42.6 \\
\hline
\end{tabular}

\section{参 考 文 献}

1）中川行夫・坪井八十二：水稲の出穂期の潮風の影 響, 農業気象, 11 ( 1 ). 1955.

2）同：風単独害と風雨害の羑異について, 農業気象 17, (2) 1955.

\section{Summary}

In order to carry out a study on the injury of rice plant caused by briny wind in its heading stage, rice plants were treated by the artificial briny wind of $12 \mathrm{~m} / \mathrm{sec}$ wind velocity in a wind tunnel spraying salt-water. The results obtained are summarized as follows :

1. The volume of salt adhered to the ears and leaves of rice plants closely related to the concentration of salt-water to be sprayed.

2. The discolouration of ear, the degree of leaf withering and the degree of sterility were accerelated with the increase of the volume of salt adhered to the ear.

3. The critical volume of salt to cause the injury was estimated to be about $1.0 \mathrm{mg}$ per ear in present experiment.

4. It was recognized that the sooner the rice plants treated by briny wind were washed by water and the greater the volume of salt adhered to the rice plants, the greater the effect of washing is.

5. The reduction of rice yield which may occur by briny wind injury seems to be predictable by inspecting the external change in the appearance of rice plant.

昭和 34 年度農学関係学会の行事について

\begin{tabular}{|c|c|c|}
\hline 会 & 学会期日 & 開催 場 所 \\
\hline 農学大会 & 4 月 4 日 & 東大農 学 部 \\
\hline 芸学会 & 4 月 7 日 $~ 8$ 日 & 京大農 学 部 \\
\hline 本育種学会 & 4 月 1 日 3 日 & 東大農 \\
\hline $\begin{array}{l}\text { 日本応用動物昆虫 } \\
\text { 学会 }\end{array}$ & 4 月 2 日 3 日 & 東大農 \\
\hline 本作物学会 & 4 月 2 日 3 日 & 東大農 学 \\
\hline 本蟇系学会 & 日 29 日 & 東 大 農 \\
\hline 本植物病理学会 & 日 4月 1日 & 東 大農 学 \\
\hline 学会 & 日 $\sim 3$ 日 & 東 大 農 \\
\hline 学会 & $\sim 10$ 日 & \\
\hline
\end{tabular}

\begin{tabular}{|c|c|c|}
\hline 日本畜産学会 & 4 月 4 日 6 日 & 東大農学部 \\
\hline 日本土壤肥料学会 & 4 月 5 日 $~ 7$ 日 & $\begin{array}{l}\text { 駒込香川 } \\
\text { 女子栄養短大 }\end{array}$ \\
\hline 日本農業気象学会 & 4 月 6 日 $\sim 7$ 日 & $\begin{array}{l}\text { 林 業 試 験 場 } \\
\text { (下目黒 }- \text { 東京) }\end{array}$ \\
\hline 日本農芸化学学会 & 4 月 8 日 10 日 & 東大農 学 部. \\
\hline 日本林学会 & 4 月 11 日 $~ 12$ 日 & 東大農 学 部 \\
\hline 農業機械学会 & 4 月 6 日〜 7 日 & 教育大学農学部. \\
\hline 日本木材学会 & 4 月 11 日 12 日 & 東大農 学 部 \\
\hline 農業土木学会 & 5 月 16 日 17 日 & 教育 \\
\hline
\end{tabular}

